\title{
Flavobacterium psychrophilum in Baltic salmon Salmo salar brood fish and their offspring
}

\author{
Elisabet Ekman ${ }^{1, *}$, Hans Börjeson ${ }^{2}$, Nils Johansson ${ }^{2}$ \\ ${ }^{1}$ Swedish University of Agricultural Sciences, Faculty of Veterinary Medicine, Department of Pathology, \\ 75007 Uppsala, Sweden \\ ${ }^{2}$ Swedish Salmon Research Institute, Forskarstigen, 81494 Älvkarleby, Sweden
}

\begin{abstract}
Baltic salmon brood fish were investigated for the presence of Flavobacterium psychrophilum in the kidney, spleen, brain and sexual products (ovarian fluid, unfertilised eggs and milt). Samples for bacteriology were taken at capture, when the fish were ascending their native river to spawn, and after a period of captivity in indoor pools, at stripping. During captivity, abnormal wiggling behaviour was recorded in some of the fish. Bacterial samples were taken to determine if $F$. psychrophilum had any role in the aetiology of the condition. Furthermore, the presence of $F$. psychrophilum on egg surfaces during incubation was investigated. F. psychrophilum was isolated from internal organs and/or sexual products in 7 out of $50(14.0 \%)$ fish sampled at capture and 63 out of $272(23.2 \%)$ fish sampled at stripping. The bacteria was isolated from either spleen or gonads in 2 out of $19(10.5 \%)$ fish with abnormal wiggling behaviour but no bacteria was isolated from the brain. No $F$. psychrophilum was isolated from eggs at the eyed stage. Just before hatching, the bacterium was isolated from 5 out of $15(33.3 \%)$ family groups. The present study shows that Baltic salmon brood fish are carriers of F. psychrophilum during their spawning migration. The presence of the bacteria in sexual products from both females and males indicates that transmission from the brood fish to the offspring should be considered an important route of infection.
\end{abstract}

KEY WORDS: Flavobacterium psychrophilum - Baltic salmon · Brood fish · Eggs · Milt · Ovarian fluid

\section{INTRODUCTION}

Exploitation of water for hydropower production in most Swedish rivers entering the Baltic Sea has reduced the possibility of anadromous fish species reaching their natural spawning habitats. In these rivers, breeding programs based on ascending sea-run spawners caught in their native rivers constitute an important instrument for retaining different river populations. Ascending Baltic salmon Salmo salar are caught in fish traps and kept in indoor pools until maturation. After artificial fertilisation and hatching, the fish are reared until smoltification, when they are released into the river. During recent decades the production of smolts has been negatively influenced by several factors. One major threat is the M74-syndrome, which causes high mortality during the alevin stage of

•E-mail: elisabet.ekman@pat.slu.se
Baltic salmon (Norrgren et al. 1993). During recent years an increased number of brood fish with abnormal behaviour has been observed, both during their migration in the river and in the holding pools. Affected fish are characterised by uncoordinated wiggling and sideways swimming. The condition has been associated with low thiamine concentrations (Amcoff et al. 1998). Furthermore, brood fish in the indoor pools are often affected by dermal fungal infections, and episodes of ulcerative dermal necrosis (UDN) have occurred (Johansson et al. 1982). Problems with skin ulcers, fin erosions and enhanced mortality often occur in growing fish in the hatcheries, especially during the late winter and early spring. In many of these cases, Flavobacterium psychrophilum can be cultured from external lesions and kidney (U.-P. Wichardt, Fish Health Control Program, Fiskhälsan FH AB, Älvkarleby, Sweden, pers. comm.).

Flavobacterium psychrophilum (formerly Cytophaga psychrophila or Flexibacter psychrophilus), the causa- 
tive agent of bacterial cold-water disease (BCWD) and rainbow trout fry syndrome (RTFS), was first isolated in 1948 in the USA from juvenile coho salmon Oncorhynchus kisutch with skin ulcers on their peduncle (Borg 1960). Disease caused by F. psychrophilum was reported only from North America until the late 1980s. Since then, several reports from Europe have described the bacterium as the causative agent of a serious septicaemic condition in rainbow trout Oncorhynchus mykiss, RTFS (Weis 1987, Bernardet et al. 1988, Baudin-Laurencin et al. 1989, Lorenzen et al. 1991, Bruno 1992, Santos et al. 1992, Toranzo \& Barja 1993a). F. psychrophilum has a worldwide distribution and outbreaks of BCWD and RTFS have been reported from Australia (Schmidtke \& Carson 1995), Japan (Wakabayashi et al. 1991) and Chile (Bustos et al. 1995). F. psychrophilum has been suggested to be transmitted both horizontally and vertically (Brown et al. 1997). Holt (1987) reported that the bacterium was present in the ovarian fluid, milt, kidney, spleen and skin mucus from sexually mature chinook salmon Oncorhynchus tshawytscha and coho salmon of both sexes. The bacterium has also been isolated from ovarian fluid, and from the surface of newly stripped, unfertilised eggs of rainbow trout (Rangdale et al. 1996) and steelhead trout O. mykiss (Brown et al. 1997). Furthermore, the bacterium has also been isolated from the inside of newly fertilised eggs, eyed eggs and newly hatched alevins (Brown et al. 1997), thereby indicating a vertical transmission from adult fish via eggs to alevins.

The aim of the present study was to investigate the presence of Flavobacterium psychrophilum in sea-run Baltic salmon brood fish, at capture at the salmon trap, at stripping (after a period of captivity) and in their offspring.

\section{MATERIAL AND METHODS}

Baltic salmon brood fish of the River Dalälven population were caught during their spawning migration in the salmon trap at the National Board of Fisheries, Älvkarleby, located $10 \mathrm{~km}$ from the mouth of the river, in the Baltic Sea. A total of 341 individuals were included in the study.

Sampling of sexually premature fish at capture. A total of 50 fish ( 45 females and 5 males) were randomly selected from the salmon trap during their spawning migration. The water temperature during sampling varied between 18 and $19^{\circ} \mathrm{C}$. The fish were killed with a blow to the head and samples from the spleen, gonads and kidney were taken for bacteriology. Samples from gonads and spleen were taken with a sterile cotton swab after incision with a sterile scalpel. Sam- ples from the kidney were taken with a cotton swab after incision, first through the swim bladder and then into the kidney, again with sterile scalpels.

Sampling of wiggling brood fish during the captivity period. A total of 291 fish were transported from the fish trap to an indoor pool supplied with flow-through river water. During the captivity period, 6 to $14 \mathrm{wk}$ after capture, 19 brood fish (18 males and 1 female) showing abnormal wiggling behaviour were killed by decapitation after anaesthetisation in MS222 $1175 \mathrm{mg}$ $\mathrm{l}^{-1}$ ) (Sandoz Ltd, Basel, Switzerland). Samples for bacteriology were taken from the brain, spleen, gonads and kidney. The head was disinfected with $70 \%$ ethanol before the skull was opened. The meninges were disinfected with $70 \%$ ethanol, and a sterile plastic loop was inserted into the right hemisphere and directly streaked onto agar plates. The spleen, gonads and kidney were sampled as described earlier. The water temperature decreased from 14 to $7^{\circ} \mathrm{C}$ during the sampling period.

Sampling of sexually mature fish at stripping. A total of 272 fish ( 232 females and 40 males), kept in an indoor pool for 3 to 4 mo until sexual maturation, were examined. Approximately 1 mo before stripping, male and female fish were sorted and separated by a fence in the pool. In connection with stripping, roe, ovarian fluid and milt samples were taken for bacteriology. During the period of sampling, the water temperature varied between 2 and $7^{\circ} \mathrm{C}$. Ovarian fluid and/or eggs were sampled in sterile glass bottles. The first volume of the ovarian fluid and the first eggs were excluded to avoid contamination from the outer surface of the fish. After stripping, the fish were killed by decapitation after anaesthetisation in MS222 (175 $\left.\mathrm{mg} \mathrm{l}^{-1}\right)$ and samples from the brain and kidney were taken aseptically for bacteriology. Milt was sampled at stripping in sterile glass bottles, a midstream sample being taken. After stripping, 20 males were killed and samples from kidney and testis were taken aseptically with cotton swabs after incision with a sterile scalpel

Sampling of roe during embryogenesis. The egg batches from 15 females were separately fertilised with milt from 15 different males. After fertilisation and water-hardening, the roe was disinfected with $1 \%$ Buffodine (Evans Vanodine International Ltd, Preston, England) for 10 min and incubated in separate hatching trays supplied with water from the River Dalalven. The temperature varied according to the normal fluctuation in the river, which ranges from 0.1 to $8^{\circ} \mathrm{C}$ from November to April. Samples for bacteriology were taken from 10 eggs of each family group at eyed stage and just before hatching.

Bacteriology. The samples were initially cultivated on a selective Cytophaga agar (SCA) with neomycin $5 \mathrm{\mu g} \mathrm{ml}^{-1}$ and polymyxin B $10 \mathrm{U} \mathrm{ml}^{-1}$ (Fijan 1969) for 
$10 \mathrm{~d}$ at $15^{\circ} \mathrm{C}$. Ten unfertilised eggs from each sampled female were rolled directly on SCA plates. Ten fertilised eggs from each family group, collected during incubation, were rinsed several times in sterile water and then shaken vigorously on a vortex stirrer for $2 \mathrm{~min}$ in $5 \mathrm{ml}$ peptone-saline $(0.1 \%$ peptone, $0.85 \%$ saline) solution and $100 \mu \mathrm{l}$ were spread on SCA agar.

Ovarian fluid, milt and cotton swabs from kidney and spleen were streaked onto SCA plates. Samples from the brain were streaked directly onto SCA plates at the time of sampling. All yellow colonies on the SCA plates were further cultivated on Cytophaga agar (CA) (Anacker \& Ordal 1959) at $15^{\circ} \mathrm{C}$. Identification of Flavobacterium psychrophilum was performed by phenotypic characteristics by comparison with the $F$. psychrophilum type strain NCIMB $1947^{\mathrm{T}}$, and results of Bernardet \& Kerouault (1989) and Bernardet et al. (1996). The phenotypic characteristics included for all isolates were: colony morphology on CA, Gram staining, presence of flexirubin pigments (Fautz \& Reichenbach 1980$)$, catalase $\left(30 \% \quad \mathrm{H}_{2} \mathrm{O}_{2}\right)$ and cytochrome

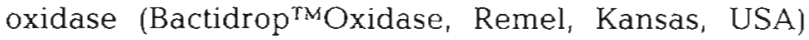
ability to grow at 6 and $30^{\circ} \mathrm{C}$ and with $0.5,1.0$ and $1.5 \% \mathrm{NaCl}$ in Cytophaga broth (CB), growth on tryptone soy agar (TSA) (LabM, England), ability to produce acid aerobically from glucose and saccharose (Pacha 1968), hydrolysis of starch (starch agar, Difco Laboratories), hydrolysis of esculin (bile esculin agar, Difco Laboratories) and reduction of nitrate (nitrate agar, Difco Laboratories). Susceptibility to the vibriostatic compound $\mathrm{O} / 129$ was tested with diagnostic discs, Oxoid DD15, O129, $150 \mu \mathrm{g}$ (Unipath LTD, England) on CA. The API-ZYM gallery (bioMérieux sa, Marcy-l'Étoile, France) was used to test 19 enzymatic activities. The strips were incubated at $18^{\circ} \mathrm{C}$ for $15 \mathrm{~h}$. Additionally 41 isolates were tested for gliding motility in a 'hanging drop' preparation from CB and hydrolysis of starch (starch agar, Difco Laboratories) and casein (1.0\% skim milk, Merck; $1 \%$ agar no. 3, Oxoid; $0.05 \%$ yeast extract, Difco Laboratories).

Statistics. To evaluate if there are any differences in proportions of Flavobacterium psychrophilum positive fish between fish sampled at the trap and fish sampled at stripping a chi-square $\left(\chi^{2}\right)$ test was performed.

\section{RESULTS}

Besides the abnormal wiggling behaviour noted in 19 fish and sporadic cases of fungal infections, no clinical signs of disease were recorded among the brood fish in this study during the captivity period.

Bacteria with phenotypic characteristics consistent for Flavobacterium psychrophilum were found in 78 out of 913 samples from sexual products, internal organs and fertilised eggs. The bacterium was isolated in pure cultures from a majority of the positive samples from internal organs and from sexual products. In samples from fertilised eggs the bacteria grew in mixed cultures. No further characterisation of isolated bacteria, other than F. psychrophilum, has been performed. The Baltic salmon isolates and the F. psychrophilum type strain showed almost identical phenotypical characteristics except that the type strain was catalase negative while the Baltic salmon isolates were weakly catalase positive.

Flavobacterium psychrophilum was isolated from 7 out of $50(14.0 \%)$ fish sampled at capture in the salmon trap. No F. psychrophilum was isolated from the 5 males but the bacterium was isolated from 7 out of 45 $(15.5 \%)$ females with 6 females positive in the kidney and 2 in the gonads.

Flavobacterium psychrophilum was isolated from 2 out of 18 males $(11.1 \%)$ showing wiggling behaviour during captivity, with 1 positive sample from spleen and 1 from the gonads. No F. psychrophilum was isolated from the only wiggling female and the bacterium was not isolated from the brain of any of the fish showing wiggling behaviour.

After captivity for 3 to 4 mo, 63 out of 272 (23.2\%) fish were positive for Flavobacterium psychrophilum in internal organs and/or sexual products. In female fish, the bacterium was isolated from 47 out of 232 $(20.2 \%)$ individuals, with positive samples from kidney $(9.2 \%)$, brain $(7.0 \%)$ and ovarian fluid $(4.7 \%)$ (Table 1). Furthermore, the bacterium was isolated from $7.7 \%$ of the egg samples. In only 4 fish was F. psychrophilum isolated from more than 1 sampled tissue, 2 with the bacterium in the kidney and brain and 2 with the bacterium in the ovarian fluid and on egg surfaces. In male fish, $F$. psychrophilum was isolated from 16 out of 40 $(40.0 \%)$ individuals. The bacterium was isolated either from milt at stripping $(22.5 \%)$, milt sampled directly

Table 1 Isolation of Flavobacterium psychrophilum from Baltic salmon brood fish at the time of stripping

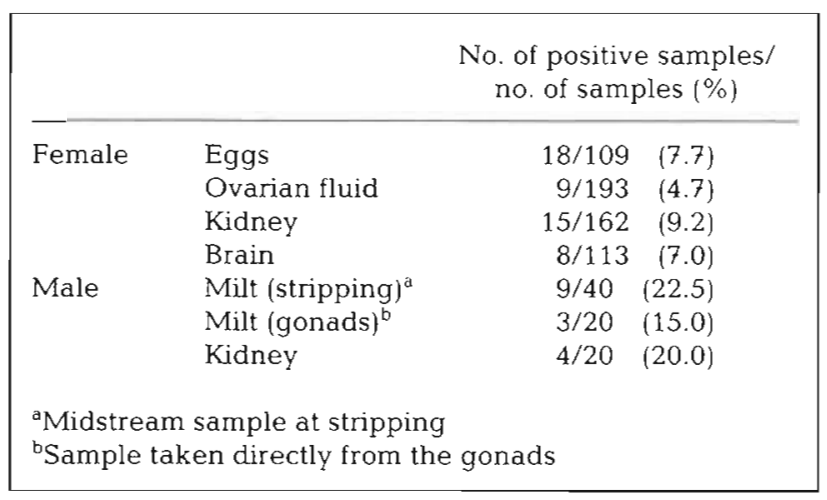


from the gonads $(15.0 \%)$, or from the kidney $(20.0 \%)$ (Table 1). None of the male fish were positive for $F$. psychrophilum in more than 1 sampled tissue.

Flavobacterium psychrophilum was not isolated from egg surfaces at the eyed stage. However, the bacterium was isolated from 5 out of $15(33.3 \%)$ family groups sampled just before hatching. No enhanced egg mortality was recorded in those 5 groups compared with the groups where no F. psychrophilum was isolated.

\section{DISCUSSION}

Yellow pigmented bacteria with phenotypic characteristics consistent with Flavobacterium psychrophilum were isolated from Baltic salmon of both sexes and from eggs during incubation. The phenotypic characters and API-ZYM profiles of the isolates and the type strain NCIMB $1947^{\top}$ were in accordance with the results of Bernardet \& Kerouault (1989), except that some of the isolates from the Baltic salmon and the type strain grew in $1 \% \mathrm{NaCl}$ in $\mathrm{CB}$. However, Pacha (1968) found that certain strains were able to grow in $1 \% \mathrm{NaCl}$. This is also supported by Holt (1987), showing growth of all tested strains in $1 \% \mathrm{NaCl}_{\text {, although in }}$ a medium with a different composition (tryptone yeast extract salts, TYES, broth).

It is uncertain during which stage of the life cycle the fish become infected. They could be chronically infected when released as smolts from the hatchery, or infected when returning to the home river for spawning. In the present study, $14.0 \%$ of the fish caught in the salmon trap were positive for Flavobacterium psychrophilum. After 2 to 3 mo in the holding pool, 23.2\% of the fish were positive in connection with stripping. This is not a statistically significant difference but might indicate that higher density of fish in the pool facilitates transmission of the bacteria. This is in accordance with Holt (1987), who reported that adult salmon that have recently entered freshwater have lower incidences of $F$. psychrophilum than those held for an extended time in freshwater prior to spawning.

Flavobacterium psychrophilum was not isolated from the brain in brood fish showing wiggling behaviour during captivity. The bacterium has earlier been isolated from brain of salmonids with abnormal swimming behaviour (Kent et al. 1989). Wiggling behaviour in Baltic salmon brood fish has been associated with low thiamine levels and a strong association between wiggling behaviour in females and M74 in their offspring has been recorded (Amcoff et al. 1998). The present study indicates that F. psychrophilum is not involved in the aetiology of wiggling behaviour in Baltic salmon brood fish.
In the present study, Flavobacterium psychrophilum was isolated from the kidney in both sexes, from the brain in females as well as from sexual products at stripping. This indicates that the brood fish are systemically infected and carriers of $F$. psychrophilum. The presence of $F$. psychrophilum in internal organs of brood fish has earlier been described by Holt (1987), who isolated the bacteria from the kidney and the spleen of coho and chinook salmon.

The highest prevalence of Flavobacterium psychrophilum was found in male fish. None of the male fish was positive in more than 1 tissue, possibly due to difficulties in isolating the bacteria. It is well known that isolation of $F$. psychrophilum may be difficult because of the fastidious nature of the bacterium (Toranzo \& Barja 1993b, Lorenzen 1994, Rangdale et al. 1996). Previously, F. psychrophilum has been isolated in milt from mature chinook and coho salmon (Holt 1987). In contrast, neither Sauter et al. (1987), studying mature coho salmon, nor Rangdale et al. (1996), studying rainbow trout, detected $F$. psychrophilum in milt. The presence of $F$. psychrophilum in the milt indicates the possibility that male fish may transfer the bacteria to the egg at the time of fertilisation.

In the present study, Flavobacterium psychrophilum was isolated from ovarian fluid samples and from the surface of unfertilised eggs. The presence of bacteria in the ovarian fluid provides an opportunity for bacterial colonisation either on the surface of the eggs or inside. Rangdale et al. (1996) were unable to isolate $F$. psychrophilum on unfertilised rainbow trout eggs while Brown et al. (1997) isolated F. psychrophilum from the surface of unfertilised steelhead trout eggs. Furthermore, Brown et al. (1997) isolated the bacterium from the inside of newly fertilised eggs as well as from eyed eggs and newly hatched alevins, indicating that $F$. psychrophilum may be vertically transmitted. F. psychrophilum was isolated from the outside of the eggs from 5 out of 15 family groups just before hatching. The eggs were disinfected after fertilisation and no $F$. psychrophilum was isolated at the eyed stage. This might indicate that the bacteria have colonised the eggs later during the incubation, probably due to the presence of $F$. psychrophilum in the water supply. Another possibility is that some of the bacteria survived the disinfection as demonstrated by Brown et al. (1997) and that the isolation of the bacteria at the eyed stage was unsuccessful.

Flavobacterium psychrophilum has been associated with mortality among eyed eggs of Atlantic salmon (Cipriano et al. 1995). No enhanced mortality was noted in the 5 infected family groups in this study. This could possibly be due to differences in the virulence of the bacteria or the use of different rearing systems. 
The present study shows that Baltic salmon of both sexes are carriers of Flavobacterium psychrophilum during their spawning migration. Furthermore, the bacterium was found in sexual products in both females and males, indicating that transmission of the bacterium from the brood fish to the offspring should be considered as an important route of infection. However, the presence of $F$. psychrophilum on the egg surfaces during the latter part of incubation indicates that the bacterium is present in the environment as well.

Acknowledgements. Thanks to Ingrid Holmgren and Kerstin Wedin, Swedish Salmon Research Institute, Älvkarleby, for skilful laboratory work during the study. This study was financially supported by the Swedish Council for Forestry and Agriculture (SJFR).

\section{LITERATURE CITED}

Amcoff P, Börjeson $H$, Lindeberg J, Norrgren L (1998) Thiamine concentrations in feral Baltic salmon exhibiting the M74 syndrome. In: McDonald G, Fitzsimons JD, Honeyfield DC (eds) Early Life Stage Mortality Syndrome in fishes of the Great Lakes and Baltic Sea. Am Fish Soc Symp 21:82-89

Anacker RL, Ordal EJ (1959) Studies on the myxobacterium Chondrococcus columnaris. 1. Serological typing. J Bacteriol 78:25-32

Baudin-Laurencin F, Castric JC, Vigneulle $M$, Tixerant $G$ (1989) La myxobactériose viscérale de la truite arc-en-ciel Salmo gairdneri $R$ : une forme nouvelle de la maladie de l'eau froide à Cytophaga psychrophila. Bull Acad Vét Fr 62:147-157

Bernardet JF, Kerouault B (1989) Phenotypic and genomic studies of Cytophaga psychrophila isolated from diseased rainbow trout (Onchorhynchus mykiss) in France. Appl Environ Microbiol 55:1796-1800

Bernardet JF, Baudin-Laurencin F, Tixerant G (1988) First identification of Cytophaga psychrophila in France. Bull Eur Assoc Fish Pathol 8:104-105

Bernardet JF, Segers P, Vancanneyt M, Berthe F, Kersters K, Vandamme P (1996) Cutting a Gordian knot: emended classification and description of the genus Flavobacterium, emended description of the family Flavobacteriaceae, and proposal of Flavobacterium hydatis nom. nov. (Basonym, Cytophaga aquatilis Strohl and Tait 1978). Int J Syst Bacteriol 46:128-148

Borg AF (1960) Studies on myxobacteria associated with diseases in salmonid fishes. American Association for the Advancement of Science, Wildlife Disease 8, Washington, DC, $p$ 1-85

Brown L, Cox WT, Levine RP (1997) Evidence that the causal agent of bacterial cold-water disease Flavobacterium psychrophilum is transmitted within salmonid eggs. Dis Aquat Org 29:213-218

Bruno DW (1992) Cytophaga psychrophila (=Flexibacter psychrophilus) (Borg), histopathology associated with mortalities among farmed rainbow trout, Oncorhynchus mykiss (Walbaum) in the UK. Bull Eur Assoc Fish Pathol 12: 215-216

Bustos PA, Calbuyahue J, Montaña J, Opazo B, Entrala P, Solervicens R (1995) First isolation of Flexibacter psychro- philus, as causative agent of Rainbow Trout Fry Syndrome (RTFS), producing rainbow trout mortality in Chile. Bull Eur Assoc Pathol 15:162-164

Cipriano RC, Ford LA, Teska JD (1995) Association of Cytophaga psychrophila with mortality among eyed eggs of Atlantic salmon (Salmo salar). J Wildl Dis 31:166-171

Fautz E, Reichenbach H (1980) A simple test for flexirubintype pigments. FEMS Microbiol Lett 8:87-91

Fijan NN (1969) Antibiotic additives for the isolation of Chondrococcus columnaris from fish. Appl Microbiol 17: $333-334$

Holt RA (1987) Cytophaga psychrophila, the causative agent of bacterial cold-water disease in salmonid fish. PhD thesis, Oregon State University, Corvallis

Johansson N, Svensson KM, Fridberg G (1982) Studies on the pathology of ulcerative dermal necrosis (UDN) in Swedish salmon, Salmo salar L., and sea trout, Salmo trutta L., populations. J Fish Dis 5:293-308

Kent ML, Groff JM, Morrison JK, Yasutake WT, Holt RA (1989) Spiral swimming behaviour due to cranial and vertebral lesions associated with Cytophaga psychrophila infections in salmonid fishes. Dis Aquat Org 6:11-16

Lorenzen E (1994) Studies on Flexibacter psychrophilum in relation to rainbow trout fry syndrome (RTFS). PhD thesis, National Veterinary Laboratory, Ånus, \& Royal Veterinary and Agricultural University, Copenhagen

Lorenzen E, Dalsgaard I, From J, Hansen EM, Hørlyck V, Korsholm H, Mellergaard S, Olesen NJ (1991) Preliminary investigations of fry mortality syndrome in rainbow trout. Bull Eur Assoc Pathol 11:77-79

Norrgren L, Andersson T, Berquist PA, Björklund I (1993) Chemical, physiological and morphological studies of feral Baltic salmon (Salmo salar) suffering from abnormal fry mortality. Environ Toxicol Chem 12:2065-2075

Pacha RE (1968) Characteristics of Cytophaga psychrophila (Borg) isolated during outbreaks of bacterial cold-water disease. Appl Microbiol 16:97-101

Rangdale RE, Richards RE, Alderman DJ (1996) Isolation of Cytophaga psychrophila, causal agent of Rainbow Trout Fry Syndrome (RTFS) from reproductive fluids and egg surfaces of rainbow trout (Oncorhynchus mykiss). Bull Eur Assoc Fish Path 16:63-67

Santos Y, Huntly PJ, Turnbull A, Hastings TS (1992) Isolation of Cytophaga psychrophila (Flexibacter psychrophilus) in association with rainbow trout mortality in the United Kingdom. Bull Eur Assoc Fish Path 12:209-210

Sauter RW, Williams C, Meyer EA, Celnik B, Banks JL, Leith DA (1987) A study of bacteria present within unfertilized salmon eggs at the time of spawning and their possible relation to early lifestage disease. J Fish Dis 10:193-203

Schmidtke LM, Carson J (1995) Characteristics of Flexibacter psychrophilus isolated from Atlantic salmon in Australia. Dis Aquat Org 21:157-161

Toranzo AE, Barja JL (1993a) Fry Mortality Syndrome (FMS) in Spain. Isolations of the causative bacterium Flexibacter psychrophilus. Bull Eur Assoc Pathol 13:30-32

Toranzo AE, Barja JL (1993b) Virulence factors of bacteria pathogenic for coldwater fish. Annu Rev Fish Dis 3:5-36

Wakabayashi $H$, Horiuchi M, Bunya T, Hoshiai G (1991) Outbreaks of cold-water disease in coho salmon in Japan. Fish Pathol 26:211-212

Weis J (1987) Über das Vorkommen einer Kaltwasserkrankheit bei Regenbogenforellen, Salmo gairdneri. Tierärztl Umschau 42:575-577 